\title{
26 Small Terrestrial Rodents in Disturbed and Old- Growth Montane Oak Forest in Costa Rica
}

\author{
M.B. VAN DEN BERGH and M. KAPPELle
}

\subsection{Introduction}

It is well known that rodents such as squirrels and mice often function as important seed dispersers and predators in temperate oak forests (Krajicek 1955; Barnett 1977; Fox 1982; Schweiger et al. 2004) and tropical lowland rainforests (Adler 1995; Ceballos 1995; Lambert and Adler 2000; Janzen and Forget 2001; Demattia et al. 2002). In tropical montane oak forests, for example, they may feed on acorns during mast seeding years, affecting tree seed germination patterns (Chap. 13). Often, ground-dwelling rodents play a prominent role in the food chain of species-rich, neotropical communities, as they serve as staple food for predators such as carnivorous birds and medium to largesized mammals (e.g., Chinchilla-Romero 1997).

However, still little is known about the responses of small terrestrial rodents to changes in forest cover as a result of habitat fragmentation and loss of tropical forest (Kasene 1984; Adler 1994). Even less is known on the role terrestrial Rodentia play in forest succession, canopy closure, and biodiversity recovery following slash-and-burn practices or commercial logging. Data on presence and abundance of small ground-dwelling rodents in disturbed tropical montane environments are much scarcer than for lowland rainforests (Kappelle 1996). Only few studies on small-sized terrestrial rodent are available for neotropical montane oak forests (e.g., Lanzewizki 1991; Johnson and Vaughan 1993).

We conducted live-trapping sessions for censusing small terrestrial rodent species populations with the aim to focus on diversity and distribution of this functional group of mammals along a disturbance gradient, ranging from cattle-grazed pasturelands to undisturbed mature, old-growth forest (van den Bergh and Kappelle 1998). Our main purpose was to identify key indicator rodent species characteristic for certain levels of disturbance and/or recovery 
Ecological Studies Vol 185, Kappelle (Ed.) - page proofs by F. Kröner, HD

in a neotropical montane oak forest, and as such, contribute to much needed knowledge for montane oak forest restoration in a fragmented landscape.

\subsection{Study Area}

The study was carried out in the core of the fragmented montane oak forest zone (2,200-2,800 $\mathrm{m}$ a.s.l.) in the upper watershed of the Savegre River, near the village of San Gerardo de Dota in the Los Santos Forest Reserve (Dota County), situated in the western part of Costa Rica's Talamanca Range. Average annual rainfall is 2,000-3,000 $\mathrm{mm}$, and average annual temperature varies in the range $10-15^{\circ} \mathrm{C}$, depending on altitude. The dry season lasts from early January to late April (Kappelle 1996). Soils are derived from volcanic ash, are acid ( $\mathrm{pH} 3.5-5.5$ ), and moderately fertile (Chap. 4). Natural vegetation is 30-50 m tall, evergreen broad-leaved oak forest (Chaps. 4 and 10). Since the beginning of the 1950s, conversion of the region's oak forests into grasslands and croplands has led to a complex landscape mosaic (Kappelle and Juárez 1995). After abandonment of low-production pasturelands in the late 1970s and early 1980s, stands of successional forests have developed along edges of old-growth forests and pastures (Kappelle et al. 1995; Chaps. 17 and 30).

\subsection{Habitat Selection}

Five different habitats were selected along a man-induced disturbance gradient in the upper montane forest belt (2,300-2,800 $\mathrm{m}$ a.s.l.). These habitats are, from low to high levels of disturbance:

1. 30-40 $\mathrm{m}$ tall, dense, old-growth oak-dominated 'closed mature forest' (CMF);

2. oak-dominated 'open mature forest', with a relatively open, 30-35 m high canopy (OMF);

3. 3-7 m high secondary 'successional shrubland' (SSL);

4. $0.5-2 \mathrm{~m}$ tall secondary 'abandoned pastureland' (APL); and

5. $<0.5 \mathrm{~m}$ high 'grazed pastureland' (GPL).

In each habitat, a 0.25 -ha plot $(50 \times 50 \mathrm{~m})$ was established, with exception of APL in which a 0.28 -ha plot $(37.5 \times 75 \mathrm{~m})$ had to be laid out due to this site's different patch shape (Table 26.1). 
Ecological Studies Vol 185, Kappelle (Ed.) - page proofs by F. Kröner, HD

Small Terrestrial Rodents

Table 26.1. Live-trapping and population data for five different habitats, sampled along a successional gradient in a fragmented neotropical montane oak forest landscape, Costa Rica

\begin{tabular}{lllllll}
\hline \multirow{2}{*}{ Plots } & \multicolumn{2}{l}{ Habitat type $^{\mathrm{a}}$} & & & \\
& CMF & OMF & SSL & APL & GPL & \multirow{2}{*}{ All } \\
\hline Plot size (ha) & 0.25 & 0.25 & 0.25 & 0.28 & 0.25 & 1.28 \\
Trap nights $^{\mathrm{b}}$ & 10.00 & 9.00 & 10.00 & 10.00 & 10.00 & 49.00 \\
Species richness $^{\mathrm{c}}$ & 4.00 & 5.00 & 4.00 & 4.00 & 4.00 & 7.00 \\
Species density $^{\mathrm{d}}$ & 92.00 & 180.00 & 160.00 & 196.00 & 80.00 & 142.00 \\
Capture frequency $^{\mathrm{C}}$ & 3.20 & 10.70 & 11.60 & 8.00 & 5.80 & 7.90 \\
Capture frequency per ha & 12.80 & 42.80 & 46.40 & 28.60 & 23.20 & 30.80 \\
\hline
\end{tabular}

a CMF, closed mature forest; OMF, open mature forest; SSL, successional shrubland; APL, abandoned pastureland; GPL, grazed pastureland

b Total number of trap nights

c Total number of species per plot

d Total number of individuals per hectare

e Mean number of captures per trap night

\subsection{Rodent Trapping}

In all but the APL plot, a total of 25 Sherman traps (trap size: $23 \times 9 \times 8 \mathrm{~cm}$ ) was placed in a $5 \times 5$ grid with a $12.5-\mathrm{m}$ distance between two neighboring traps, in order to trap small mammals alive. Similarly, in APL 28 traps were located in a $4 \times 7$ grid. A standardized capture-recapture method was used to estimate species diversity, distribution and abundance in each habitat type (Leslie 1952). Plots were studied from April to June, covering the transition from the dry to the wet season. Sherman traps were checked before noon during 10 consecutive days (Table 26.1). Only OMF traps were checked over 9 days. Bait consisted of a mixture of rolled oats and peanut butter with a touch of vanilla flavor. During afternoons, traps were checked for diurnal catches and bait was renewed for the next trap-night. Traps were covered with litter and/or leaves for camouflage and insulation.

\subsection{Data Collection and Analysis}

We recorded data on the presence, sex, weight, and length of trapped individuals. Weight was measured using a Pesola pocket scale (max. weight $300 \mathrm{~g}$ ). Length measurements included the head-body length, measured from the tip of the nose to the inflection point of the tail, and the tail length, measured 
Ecological Studies Vol 185, Kappelle (Ed.) - page proofs by F. Kröner, HD 340

M.B. van den Bergh and M. Kappelle

from the inflection point with the body to the fleshy tip of the tail. On-site species identification was done with the aid of Emmons' (1990) field guide, after studying rodent specimens in Costa Rica's national collections. Control specimens were collected and stored at the country's National Museum. Collected specimens were identified with help of B. Rodríguez (personal communication, at the National Museum in San José), and on basis of field guides (Mora and Moreira 1984; Emmons 1990). Trapped individuals were marked upon first capture with acrylic paint before being released.

\subsection{Rodent Species Diversity}

Seven rodent species distributed over two families (five Muridae, two Heteromyidae) were represented in a total of 389 captures (185 individuals; Table 26.2). The most abundant species was Peromyscus mexicanus (Mexican

Table 26.2. Data on abundance and captures of seven rodent species for five different habitats, sampled along a successional gradient in a fragmented neotropical montane oak forest landscape, Costa Rica

Habitat type
CMF OMF SSL APL GPL All plots

\begin{tabular}{|c|c|c|c|c|c|c|}
\hline \multicolumn{7}{|l|}{ Abundance $^{b}$} \\
\hline Peromyscus mexicanus & 19 & 21 & 17 & 13 & 5 & 75 \\
\hline Scotinomys xerampelinus & 3 & 7 & 20 & 24 & 7 & 61 \\
\hline Oryzomys albigularis & 1 & 7 & 1 & 0 & 6 & 15 \\
\hline Reithrodontomys creper & 0 & 6 & 0 & 9 & 0 & 15 \\
\hline Reithrodontomys cf. sumichrasti & 0 & 0 & 0 & 9 & 2 & 11 \\
\hline Heteromys oresterus & 2 & 4 & 0 & 0 & 0 & 6 \\
\hline Heteromys cf. desmarestianus & 0 & 0 & 2 & 0 & 0 & 2 \\
\hline Total (all species) & 25 & 45 & 40 & 55 & 20 & 185 \\
\hline \multicolumn{7}{|l|}{ Captures $^{c}$} \\
\hline Peromyscus mexicanus & 26 & 67 & 58 & 26 & 30 & 207 \\
\hline Scotinomys xerampelinus & 3 & 12 & 44 & 29 & 14 & 102 \\
\hline Oryzomys albigularis & 1 & 12 & 1 & 0 & 9 & 23 \\
\hline Reithrodontomys creper & 0 & 9 & 0 & 15 & 0 & 24 \\
\hline Reithrodontomys cf. sumichrasti & 0 & 0 & 0 & 10 & 5 & 15 \\
\hline Heteromys oresterus & 2 & 4 & 0 & 0 & 0 & 6 \\
\hline Heteromys cf. desmarestianus & 0 & 0 & 12 & 0 & 0 & 12 \\
\hline Total (all species) & 32 & 104 & 115 & 80 & 58 & 389 \\
\hline
\end{tabular}

Ecological Studies Vol 185, Kappelle (Ed.) - page proofs by F. Kröner, HD 
Ecological Studies Vol 185, Kappelle (Ed.) - page proofs by F. Kröner, HD

Small Terrestrial Rodents

Deer Mouse, ratón pata blanca, closely related to P. nudipes, the Naked-footed Deer Mouse, which is common at Monteverde; Anderson 2000), with 75 individuals recorded in 207 captures (Table 26.2). The other six species were Scotinomys xerampelinus (Singing Mouse, ratón cantante), Oryzomys albigularis (White-throated Rice Rat, ratón arrocero), Reithrodontomys creper (Chiriquí Harvest Mouse, ratón de las cosechas), $R$. cf. sumichrasti (Sumichrasti's Harvest Mouse, ratón de las cosechas), and Heteromys oresterus and H. cf. desmarestianus, both being Spiny Pocket Mice (ratas de campo). Rodent species richness was very similar for all habitat sites, with $4-5$ species per habitat regardless of its position along the disturbance axis.

\subsection{Rodent Body Sizes and Abundance}

Average head-body lengths of individuals ranged from $6.9 \mathrm{~cm}$ for Scotinomys xerampelinus to $14.8 \mathrm{~cm}$ for Oryzomys albigularis. Similarly, average tail lengths of individuals ranged from $5.9 \mathrm{~cm}$ for Scotinomys xerampelinus to $17.1 \mathrm{~cm}$ for Oryzomys albigularis (Table 26.3). The latter had the largest weight (average of $93.4 \mathrm{~g}$ ), whereas Scotinomys xerampelinus had the lowest average weight $(14.0 \mathrm{~g})$.

Population density and capture frequency (absolute and per area values) were higher in habitats suffering intermediate levels of disturbance, being

Table 26.3. Data on sex, weight, and head-to-body and tail lengths of seven rodent species captured along a successional gradient in a fragmented neotropical montane oak forest landscape, Costa Rica

\begin{tabular}{llllll}
\hline & Males & Females & Weight $^{\mathrm{a}}$ & HB-length $^{\mathrm{b}}$ & T-length $^{\mathrm{c}}$ \\
\hline Peromyscus mexicanus & 43 & 32 & $51.6 \pm 4.6$ & $11.9 \pm 0.7$ & $12.3 \pm 0.6$ \\
Scotinomys xerampelinus & 36 & 25 & $14.0 \pm 2.2$ & $6.9 \pm 0.4$ & $5.9 \pm 0.8$ \\
Oryzomys albigularis & 8 & 7 & $93.4 \pm 14.2$ & $14.8 \pm 0.9$ & $17.1 \pm 2.8$ \\
Reithrodontomys creper & 13 & 2 & $22.8 \pm 2.9$ & $8.7 \pm 0.8$ & $13.0 \pm 1.0$ \\
Reithrodontomys cf. sumichrasti & 4 & 7 & $14.9 \pm 2.5$ & $7.4 \pm 0.5$ & $8.7 \pm 0.8$ \\
Heteromys oresterus & 2 & 4 & $74.8 \pm 3.8$ & $12.7 \pm 0.8$ & $17.0 \pm 0.7$ \\
Heteromys cf. desmarestianus & 1 & 1 & $24.0 \pm 5.0$ & $8.8 \pm 0.3$ & $9.8 \pm 1.3$ \\
Total (all species) & 107 & 78 & - & - & - \\
\hline
\end{tabular}

a 1 Weight $($ mean $\pm 1 S D)$ in $g$, based on measurements taken at each individual's first catch

b HB-length (mean $\pm 1 S D$ ) corresponds to the head-body length (length from the tip of the nose to the inflection point of the tail) of an individual; HB-length in $\mathrm{cm}$, based on measurements taken at each individual's first catch

c T-length (mean $\pm 1 \mathrm{SD}$ ) corresponds to the tail length (length from the inflection point with the body to the fleshy tip of the tail) of an individual; T-length in $\mathrm{cm}$, based on measurements taken at each individual's first catch 
Ecological Studies Vol 185, Kappelle (Ed.) - page proofs by F. Kröner, HD

twice as high in OMF, SSL, and APL. Abundance values differed strongly among species. Males (107 in total) appeared to prevail over females (78) in captures (Table 26.3).

\subsection{Changes Along the Disturbance Gradient}

This study presents results on small rodents that were live-trapped in mature and recovering montane oak forest in Costa Rica, in order to evaluate the relative distribution of species to each other and to microhabitat properties found along a successional gradient. Species diversity and abundance of small terrestrial rodents proved to be relatively high, with murid species being dominant. Observed abundance values were concordant with classical rankabundance values (Magurran 1988). High abundances (60-75 individuals) were recorded for $P$. mexicanus and S. xerampelinus, whereas the other three Muridae, O. albigularis, R. creper and R. cf. sumichrasti, appeared to be four to five times less common. As López Barrera and Manson (Chap. 13) point out, mast seeding may produce a large pulse of food resources that allow populations of acorn (Quercus seed) predators and/or dispersers such as Peromyscus spp. to increase into the following year. However, so far it is unknown if mast seeding occurred in Costa Rican Quercus species the years (1994-1995) before we conducted live trapping (1996) at the study site.

Together, P. mexicanus and S. xerampelinus represented $79.4 \%$ of all captures (including recaptured individuals), and $73.5 \%$ of all captured individuals. Both Heteromyidae species, by contrast, seemed to be rather rare in the area ( $\leq 6$ individuals), and appeared to avoid both abandoned and grazed pasturelands. P. mexicanus and S. xerampelinus occurred at all five sites, although they differed in habitat preference, $P$. mexicanus appearing with higher numbers in CMF and OMF, and S. xerampelinus showing higher abundance in SSL and APL. This difference is explained by the fact that the latter, more insectivorous species requires a rather dense vegetation cover at ground level, as its peak in activity is during morning hours (Hooper 1972).

\subsection{Habitat Preferences}

The species O. albigularis preferred OMF as well as the edge of GPL bordering mature forest. This observation is consistent with data presented earlier by Timm et al. (1989) for the Braulio Carrillo Park in northern-central Costa Rica. R. creper and R. cf. sumichrasti were most abundant in APL. These observations are concordant with data on habitat preferences of Nicaraguan Reithrodontomys species (Jones and Genoways 1970). R. creper was also trapped 
Ecological Studies Vol 185, Kappelle (Ed.) - page proofs by F. Kröner, HD

Small Terrestrial Rodents

in OMF, but in lower numbers. Similarly, two individuals of $R$. cf. sumichrasti occurred in GPL. Low capture results of H. oresterus and H. cf. desmarestianus suggest these species' rarity in the area. Whereas $H$. oresterus preferred mature forest habitats, $H$. cf. desmarestianus was recorded only in SSL. $H$. oresterus may be qualified as an indicator species for low levels of disturbance.

In general, male individuals were more often trapped in CMF and OMF as well as APL, whereas males and females appeared equally in SSL and GPL. Whether these capture differences between sexes is due to behavior or population composition remains unknown. O. albigularis was the largest terrestrial rodent species captured, being over six times as heavy and twice as long as $R$. cf. sumirachrasti. Data on weight and head-body and tail lengths of captured individuals were in accordance with data in Emmons (1990), with the exception of values recorded for $H$. cf. desmarestianus. Individuals of this species were much smaller in this study than the data range given by these authors would suggest (49-103 g, 10.8-14.8 cm). The weight distribution for male and female individuals of the most abundant species, $P$. mexicanus, clearly illustrates within-species weight differences found between sexes in rodents.

\subsection{Conclusions}

Results are generally consistent with those presented by Lanzewizki (1991), and Johnson and Vaughan (1993), who recorded five myomorph species of which $P$. mexicanus ( $P$. nudipes, in their study) and S. xerampelinus were most common. Our study revealed seven species of terrestrial myomorph rodents, including $O$. albigularis and $H$. oresterus as new local records. Both datasets indicate the importance of within-habitat micro-environmental heterogeneity for rodent populations in these forests.

Although most species were not confined to a specific successional forest phase, Heteromys species did seem to prefer older stages such as closed and open mature forest. However, the data did not suffice for a thorough analysis of co-occurrences of species and variability between local species assemblages. More grid-based plots (replicates) need to be sampled during longer trapping sessions, preferably over a series of consecutive years, in order to achieve statistically reliable results. The results presented only support a much-needed first inventory of species, and offer preliminary insights into species abundance and habitat preference. Large-scale, long-term species monitoring is required to assess the current status and trends of small terrestrial rodent species populations and assemblages in neotropical montane oak forests. 
Ecological Studies Vol 185, Kappelle (Ed.) - page proofs by F. Kröner, HD

Acknowledgements We are grateful to A.M. Cleef and F. Bouman for providing scientific guidance. A. Velázquez gave helpful advice and practical support and B. Rodríguez identified rodents. The hospitality of the rural families in San Gerardo de Dota is much appreciated. Funding was provided by the Netherlands Organization for Scientific Research (NWO, grant 895.100.003), University of Amsterdam, the Hugo de Vries and Van Tienhoven Foundations, the European Science Foundation and Bever Outdoor Sports. The VZZ Association provided Sherman traps. Research permission was kindly provided by Costa Rica's Ministry of Environment and Energy (MINAE).

\section{References}

Adler GH (1994) Tropical forest fragmentation and isolation promote asynchrony among populations of a frugivorous rodent. J Anim Ecol 63:903-911

Adler GH (1995) Fruit and seed exploitation by Central American spiny rats. Proechimys semispinosus. Stud Neotrop Fauna Environ 30:237-244

Anderson SD (2000) Reproduction and dynamics of deer mice. In: Nadkarni NM, Wheelwright NT (eds) Monteverde: ecology and conservation of a tropical cloud forest. Oxford Univ Press, New York, pp 238-239

Barnett RJ (1977) The effect of burial by squirrels on germination and survival of oak and hickory nuts. Am Midl Nat 98:319-330

Ceballos G (1995) Vertebrate diversity, ecology and conservation in neotropical dry forests. In: Bullock SH, Mooney HA, Medina E (eds) Seasonally dry tropical forests. Cambridge Univ Press, Cambridge, UK, pp 195-220

Chinchilla-Romero FA (1997) Diet of Panthera onca, Felis concolor and Felis pardalis (Carnivora: Felidae) in Parque Nacional Corcovado, Costa Rica. In: Anon (ed) Abstr Vol Association of Tropical Biology Annu Meet, San José, p 47

Demattia EA, Curran LM, Rathcke BJ (2002) Effects of small rodent seed predators on forest recruitment in Corcovado National Park, Costa Rica. In: Anon (ed) Abstr Vol Ecological Society of America Annu Meet, Tucson, AR, pp 111-112

Emmons LH (1990) Neotropical rainforest mammals: a field guide. Univ Chicago Press, Chicago, IL

Fox JF (1982) Adaptation of gray squirrel behavior to autumn germination by white oak acorns. Evolution 36:800-809

Hooper ET (1972) A synopsis of the rodent genus Scotinomys. Museum of Zoology, University of Michigan, Occ Pap 665:1-32

Janzen PA, Forget PM (2001) Scatter-hoarding rodents and tree regeneration. In: Bongers F, Charles-Dominique P, Forget PM, Thery M (eds) Nouragues: dynamics and plant-animal interactions in a Neotropical rainforest. Kluwer, Dordrecht, pp 275-288

Johnson WE, Vaughan C (1993) Habitat use of small terrestrial rodents in the Costa Rican highlands. Rev Biol Trop 41:185-191

Jones JK Jr, Genoways HH (1970) Harvest mice (genus Reithrodontomys) of Nicaragua. W Found Vert Zool Occ Pap, vol 2

Kappelle M (1996) Los bosques de roble (Quercus) de la Cordillera de Talamanca, Costa Rica: biodiversidad, ecología, conservación y desarrollo. Instituto Nacional de Biodiversidad (INBio), Santo Domingo de Heredia

Kappelle M, Juárez ME (1995) Agroecological zonation along an altitudinal gradient in the montane belt of the Los Santos Forest Reserve in Costa Rica. Mount Res Dev 15(1):19-37 
Ecological Studies Vol 185, Kappelle (Ed.) - page proofs by F. Kröner, HD

Small Terrestrial Rodents

Kappelle M, Kennis PAF, de Vries RAJ (1995) Changes in diversity along a successional gradient in a Costa Rican upper montane Quercus forest. Biodiv Conserv 4:10-34

Kasene JM (1984) The influence of selective logging on rodent populations and the regeneration of selected tree species in the Kibale forest, Uganda. Trop Ecol 25:179-195

Krajicek JE (1955) Rodents influence red oak regeneration. USDA Forest Service, Centr Stat For Exp Sta Note no 91:1-2

Lambert TD, Adler GH (2000) Microhabitat use by a tropical forest rodent, Proechimys semispinosus, in Central Panama. J Mammol 18(1):70-76

Lanzewizki T (1991) Populationsökologische Untersuchungen an Kleinsäugern in einem Eichen-Wolkenwald (Quercus spp.) der Montanstufe Costa Ricas. MSc Thesis, Philips-Universität, Marburg, Germany

Leslie PH (1952) The estimation of population parameters from data obtained by means of the capture-recapture method. II. The estimation of total numbers. Biometrika 39:362-88

Magurran AE (1988) Ecological diversity and its measurement. Croom Helm, London, UK

Mora JM, Moreira I (1984) Mamíferos de Costa Rica. Universidad Estatal a Distancia (UNED), San José, Costa Rica

Schweiger EW, Holt RD, Pierotti R, Diffendorfer J (2004) The relative importance of small-scale and landscape-level heterogeneity in structuring small mammal distributions. In: Barrett GW, Peles JD (eds) Landscape ecology of small mammals. Springer, Berlin Heidelberg New York, pp 175-211

Timm RM, Wilson DE, Clauson BL, Laval RK, Vaughan CS (1989) Mammals of the La Selva-Braulio Carrillo Complex, Costa Rica. US Fish and Wildlife Service, North American Fauna, vol 75

Van den Bergh MB, Kappelle M (1998) Diversity and distribution of small terrestrial rodents along a disturbance gradient in montane Costa Rica. Rev Biol Trop $46(2): 331-338$ 